\title{
SAVE THE 4 DOLPHINS FROM RIMINI DOLPHINARIUM, THE SUPREME COURT MAINTAIN THEIR CONFISCATION
}

\section{Carla Campanaro}

Attorney at law in Rome and Responsible of Lav Legal Office

The Italian Supreme Court (Corte di Cassazione) on the 24 September has deposited the sentence about the confiscation of the 4 dolphins that had been carried away from the Rimini Dolphinarium from the Italian environmental police (Corpo Forestale dello Stato) and the Rimini Public Prosecutor in the august 2013, confirming the confiscation of the animal, the first time in Europe we talk about mistreatment of dolphins in a private structure. During the inquiry the prosecutor and the police helped from a big team of veterinary from the Ministry of Health and Environmental had discovered that the 4 dolphins were kept in too much little space for their ethological needs and in violation of law, and this thing caused big stress and sufferance for the animals, that furthermore weren't separated how was necessary between male and female, causing for that big problem of health for one of the young dolphins, Lapo, who was constricted to live still with this mother in few meter and a other male causing big psychophisical sufferance. Also, to cover the big stress and sufferance of the animals, the police and the veterinary discovered that the dolphins were drugged from the vet of the structure, to resist to all the work (daily exercise for the public) 
they were forced. In august 2013 public prosecutor decided to confiscated all the animals, that were carried to the Genova Acquarium, and even the Appeal Court had confirmed tha confiscation. The structure has so appealed to the Supreme Court, observed that there weren't too much proof to verify mistreatment of the animals, and that anyway there wasn't the intention of the owners of hurt them, so it was missing the malice who is necessary for the Italian criminal code to punish mistreatment, also they observed that this confiscation had stopped all they economic activity causing big problems for the workers of the dolphinarium. The Third Section (specialized in environmental law) of Supreme Court with the sentence $n$. 39159deposited the 24 September 2014 has confirmed the confiscation of the animals, establishing an important principle for animal rights, or rather that to have mistreatment is not necessary physical lesion of the health of the animals, but is enough their sufferance by sensory deprivation of the ethological needs of the animals that the team of veterinary has found during the control. Furthermore even the pharmacological treatment made not to nurse the animals but to make them work more and resist to the sufferance they were causing can be considered mistreatment so the violation, in this provisory phase of the trial, of the criminal code is proofed. This inquire is begun with a big campaign of LAV who has asked to the Ministry of Health and Environmental to make more control in this structure that till that moment hadn't had any control. 
dA derecho ANIMAL la web center de los animales con derecho

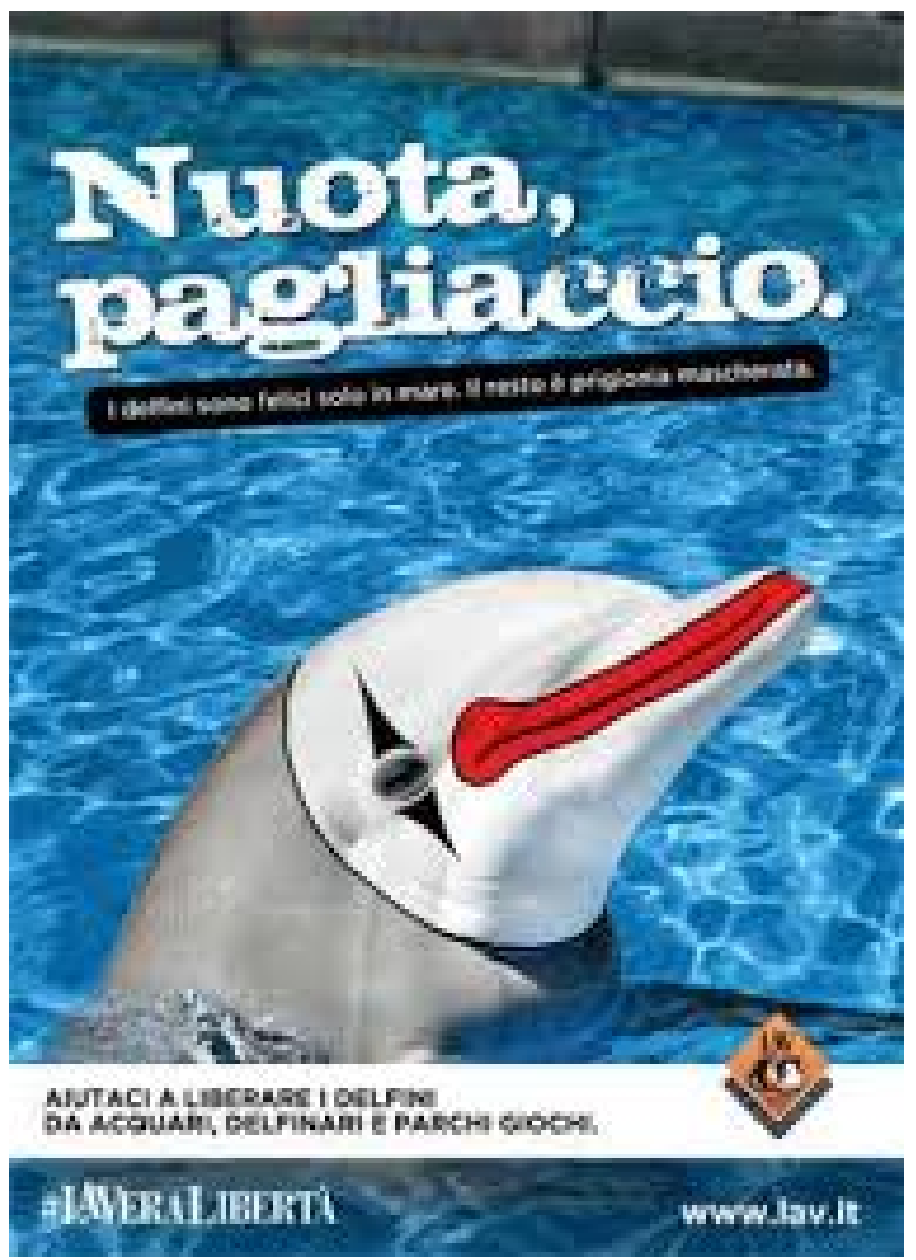

